Giresun University, agngr89@gmail.com, Giresun-Turkey

\title{
ÇİZGİ ROMANDA KADIN BEDENİ VE CİNSİYET TEMSİLI: GRAFİK KADINLAR
}

\section{Öz}

Çizgi Roman disiplini, toplumsal cinsiyet çalışmaları ve kültürel değerler açısından geçmişten günümüze araştırılmayı bekleyen sınırlı bir alandır. Özellikle çizgi romanda kadın bedeninin temsil sorunu, erkek bakışının ve söyleminin etkisiyle bugünlere kadar gelerek sektörde aynı tip kadın karakterlerin yaratılmasını sağlamıştır. Böylece hikayelerde ve illüstrasyonlarda grafik kadınlar olarak nitelendirilen sembolik kimlikler ortaya çıkmıştır. Bu grafik kadınlar, ister bir satış politikası olsun isterse bir erkek beğeni ürünü kadın bedeninin nesneleştirilen hâlidir. Bu yüzden erkek okur için çizgi romanda kadın karakterler, nesneleştirilen arzu bedenlere dönüşür. Fakat çizgi romanı okuyan yalnızca erkekler değildir, kadın okurun varlığı yine bu noktada unutulmamalıdır. İşte tüm bu bilgiler ışığında, bu çalışmada çizgi romanlarda yer alan çoğu kadın karakterin pornografik unsurlar katılarak nesneleştirilmesi ve günlük hayatta yer alan kadınları yansıtmayarak temsil sorununu doğurmasından dolayı; kültürel yapı, toplumsal cinsiyet, feminist gelişim ve kadın söylemi üzerinden ele alınması amaçlanmıştır. Bu amaç doğrultusunda çalışmanın bulgularının ölçülebilir objektif verilere dayandırılabilmesi için anket çalışması yapılmıştır. Çalışma bulgular üzerinden eleştiri ve önerilerle sonuçlandırılmıştır.

Anahtar Kelimeler: Çizgi Roman, Toplumsal Cinsiyet, Kadın Bedeni, Grafik Kadınlar, Temsil

\section{FEMALE BODY AND GENDER REPRESENTATION IN COMICS: GRAPHIC WOMEN}

\section{ABSTRACT}

Comic book discipline is a restricted area that has been awaiting research form past to present in terms of gender studies and cultural values. Particularly the representation problem of the female body in comic books has continued until these days with the influence of the male perspective and discourse and enabled the creation of the same type of female characters in the sector. Thus symbolic identities that are described as graphic women have merged in stories and illustration. These graphic women, whether a sales policy or a product of male taste, are an objectification version of the female body. Therefore female characters in comic books turn into objectified bodies of desire for the male reader, However, it is not only men who read the comic books, the presence of a female readers should not be forgotten at this point. In the light of all this information, since most of the female characters in the comics are objectified by the addition of pornographic elements and they create the problem of representation by not reflecting the women in daily life; It is aimed to be addressed through cultural structure, gender, feminist development and women's discourse. In line with this purpose, a survey study was conducted in order to base the findings of the study on measurable objective data. The study was concluded with criticism and suggestions based on the findings.

Keywords: Comic Book, Gender, Female Body, Graphic Women, Representation

How to Cite:

Güngör, A., (2021). Çizgi Romanda Kadın Bedeni ve Cinsiyet Temsili: Grafik Kadınlar. Fine Arts, 16(2):78-97, DOI: 10.12739/NWSA.2021.16.2.D0274. 


\section{GİRIŞ (INTRODUCTION)}

Tikel varlık, bir tür içerisinde ayrım yapılarak yalnızca diğer türe ilişkin olandır. Örneğin; çizgi roman piyasasında daha çok erkeklere yönelik çizgi romanlar ve karakterler üretilmektedir. Bu bağlamda çizgi roman alanında da erkek hegomanyasının etkisiyle bir tikelleşme söz konusu olduğu söylenebilir. Çizgi romanın bir türe aitmiş gibi gösterilmesi ya da satış politikaları kapsamında daha çok kimler için yapıldığının sorgulanması çalışma adına önemli bir olgudur. Çizgi romanların ortaya çıkış kültürü incelendiğinde, karikatür merkezli mizahi yönüyle çocuklara hitap ederek başlamış, zamanla erkeklerin kadınları görmek istedikleri gibi resmedildiği bir alana dönüşmüşür. Fakat bu noktada sorulması gereken soru, "Başlangıçta çizgi roman çizerleri kadın yoğunluklu olsaydı durum nasıl olurdu?" düşüncesidir. Bu yüzden geçmişte kadın karakterlere bu kadar nesneleştirme ve pornografi unsurları yansıtılmasaydı daha dişil bir söylem çizgi roman sektöründe hakim olabilirdi. Öte yandan ülkelerdeki savaş gibi nedenlerden dolayı sonrasında çizgi romanlar, bir umut ve eğlence aracı hâlini almıştır.

Bir süre sonra da insanların bir kurtarıcıya ihtiyaç duymasıyla yaratılan karakterler çoğunlukla erkek süper kahramanlardan oluşmaya başlamıştır. Böylece o zamanki dönem, çizgi roman alanında erkek süper kahramanların çă̆ı olarak nitelendirilmiştir. Öyleyse kadın karakterler ya da bir cinsiyet olarak kadın temsilinin çizgi romanda nasıl yer bulduğunun sorgulanması çalışmanın amaçlarının gerçekleştirilebilmesi bağlamında önem arz etmektedir. Örneğin; "Türkiye'de 1960 ve 70'li yıllarda Tina, Çiğdem, Nilüfer isimli genç kız ve kadınlara yönelik çizgi roman dergileri ve içlerinde öncelikle kadın okuyucuları hedef alan çizgi romanlar yayınlanmıştır" [20]. Bu çizgi romanlar, kültürel değerlerin ve toplumun yarattığı(hanım hanımcık, usturuplu vb.)kadın algısı üzerinden çizgi romanların üretilmesini sağlamıştır. Dolayısıyla kadın karakterler sadece erkekler tarafından nesneleştirilmekle kalmayarak toplumsal ve kültürel olarakta şekillendirilmeye çalışılmıştır. Yine Trina Robbins yaratmış olduğu Wimmen's Comix adlı çizgi roman antolojisi hakkında kadınlara ve kız çocuklarına yönelik dile getirilen söylemleri şu şekilde ifade etmiştir: "O zamanlar feministler, başlıklarımda kız kelimesinin kullanılması konusunda tam anlamıyla çılgın değildiler."

Yeni düşünce, siyahi bir çocuk için erkek çocuk tabiri nasıl aşağılayıcı bir terimse, kızın da aşağılayıcı bir terim olmasıydı" [30]. Yeri geldiğinde seksi bir süper kahraman, yeri geldiğinde de hanım hanımcık olan bu genç kız ve kadın karakterler, çizgi roman sektöründe çoğu zaman bedenselleştirilerek farklı göstergelerle izlenilebilen ve arzulanan varlıklara dönüşüşlerdir. Bu kapsamda çalışmada kadının cinsiyet temsilinin sorgulanabilmesi için öncelikle; "John Stuart Mill'de Kadının Toplumsal Konumu" adlı makalesi aracılığıyla toplumsal değerlerin ve kadın çalışmalarının gelişimi üzerinden çizgi romanda yaratılan grafik kadınların incelenmesi hedeflenmiştir. Aynı zamanda çizgi romanda nesneleştirmenin salt kadın karakterlere yapılmadığının doğrulanması açısından bazı erkek karakterlere de çalışmada yer verilmiştir. Bu verilerin ölçülebilir olarak değerlendirilebilmesi adına anket tekniği kullanılarak çalışma eleştiri ve önerilerle sonuçlandırılmıştır.

\section{2. ÇALIŞMANIN ÖNEMI (RESEARCH SIGNIFIANCE)}

$\mathrm{Bu}$ çalışmada çizgi romanlarda yaratılan kadın karakterlerin nesneleştirilmesinin toplumsal cinsiyet ve kadın bedeni açısından önemi vurgulanmaktadır. Fakat çizgi romanlarda kadın karakterler kadar bazı erkek karakterlerinde (Anti kahramanlar, Süper Man, Temel Reis 
vb.) nesneleştirme unsurlarına maruz kaldığı çizgi romanlarda yapılan gözlemler sonucunda ortaya çıkmıştır.

\section{YÖNTEM (METHOD)}

Bu çalışmada nitel araştırma yöntemi kullanılmış olup, içerik literatür tarama tekniği ile oluşturulmuştur. Çalışmada başlangıç olarak çizgi romandaki grafik kadınlar, toplumsal ve kültürel bilgiler doğrultusunda betimsel analiz yöntemiyle ele alınmıştır. Ayrıca çizgi romanlarda toplumsal cinsiyet yaklaşımının; temsil sorunu, nesneleştirme ve pornografi gibi konular üzerinden incelenerek tümevarım yöntemi kullanılmıştır. Bu durumun hem kadın hem de erkek okuyucular için ne ifade ettiğinin test edilebilmesi adına anket tekniğinden yararlanılarak elde edilen veriler doğrultusunda çalışma sonuçlandırılmıştır.

\section{4. ÇİZGI ROMANDAKI GRAFİK KADINLAR (GRAPHIC WOMEN IN COMIC BOOKS)}

Edebiyattan sanata, karikatürlerden çizgi romana kadar birçok alanda kadınların sayı olarak azlığı her zaman dikkat çekmiştir.



Görüntü 1. Anne Harriet Fish, Awful Week-ends, 1920 [16]

(Image 1. Anne Harriet Fish, Awful Week-ends, 1920 [16])

Ahu Antmen bu durumla ilgili şöyle bir açıklamada bulunmuştur: "Sanat tarihinin feminist bakış açısıyla sorgulanması 1971'de Linda Nochlin'in "Neden Hiç Büyük Kadın Sanatçı Yok?" başlıklı makalesiyle başlar" [2]. Bu açıklamadan yola çıkarak özellikle çizgi romanlarda, eril söylemin hakim olması ve kadına; sadece seksi ve güzel süper kahramanlar olarak yer verilmesi bu durumu doğrular niteliktedir. Bu nedenle güzel sanatlar alanında geçmişte birçok kadın çizer veya sanatçı cinsiyetini saklayarak üretimlerini yaparken, "ya erkek ismi kullanmış ya da, cinsiyet ayrımcılığına engel olmak adına Anne Harriet gibi "Fish" isimli cinsiyetsiz ve toplumsal kimlik yapısını içermeyen imzalar" kullanmışlardır [20] (Görüntü 1). Doğal olarak erkek egemen bir toplumda kadınlar kendilerini var edebilmek için, çoğu zaman kendi kimliklerini saklama ihtiyacı içerisinde hissetmişlerdir. "Kadının toplumdaki yeri sorunu da, cinsiyet ayrımına bağlı olarak ortaya çıkan kadınların ezilmesi ve ikincileştirilmesidir" [17]. Bu durum toplumsal cinsiyet çalışmaları ve çizgi roman araştırmaları arasında bağlantı kurmak için benzersiz biçimsel unsurlar sağlamaktadır. Böylelikle çoğu araştırmacı çizgi romanların bilinçli bir şekilde inşa edildiğinin belirtmiştir. Ayrıca günümüzde çoğu kişi tarafından cinsiyet, toplumsal kültürde insanların kendilerini şekillendirdikleri ve ona 
göre davranış ve yaşam biçimlerini yapılandırdıkları bir temsil olarak anlaşılmaktadır. Dolayısıyla kadın bedeninin çizgi romandaki temsilini anlamak ve değerlendirmek için metodoloji ihtiyacı ortaya çıkmıştır. Bu metodoloji belirlenirken kadın bedeni için kültürel beklentiler ve kadın bedeninin temsilinin feminist bir çerçevede incelenmesi çalışmanın gelişimi açısından bir gerekliliktir. Çünkü; gerçek yaşamda toplumsal cinsiyet unsurları olduğu gibi çizgi romanlarda da kadın bedenine karşı toplumsal cinsiyet yargıları bulunmaktadır.

Örneğin; ister çizgi roman tarihinin erken dönem çalışmaları olsun isterse modern çizgi roman örnekleri, çoğu çizgi romanda kadınlar ya pornografik unsurlarla seksi birer beden olarak çizilmiş ya da başrol erkek kahramanın yanında kurtarılmaya muhtaç bir kadın ya da süper kahraman olarak ikonlaştırılmıştır (Görüntü 2). Yani çizgi romanlarda gösterilen ya da temsil edilen kadınlar, erkek bakışı "nasıl görürse" öyle okunmak durumunda kalmıştır. Rocco Versaci bu durumu, "çizgi roman okuduğunu söylemenin bir yolu olarak genellikle grafik dili okumayı tercih ettiğini" belirtmiştir [35]. Bu açıdan çizgi romanlarda kullanılan dilin ironik yapısına değinmek için grafik terimi kullanılarak, kadın bedeni çizgi romanlarda belli bir kalıpta resmedilen simgelere ve tarza dönüşmektedir.

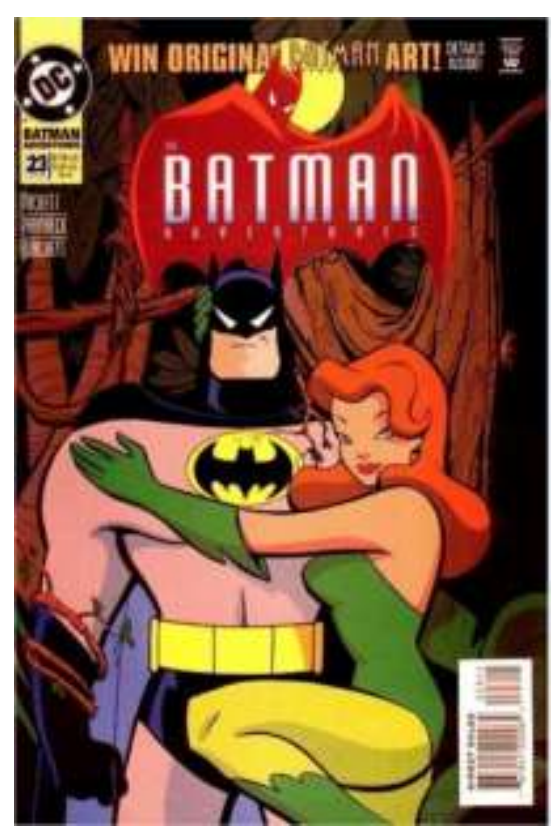

Görüntü 2. Rick Burchett ve Mile Parobeck, Batman Adventures Vol 1 \#23, August/1994 [28]

(Image 2. Rick Burchett ve Mile Parobeck, Batman Adventures Vol 1 \#23, August/1994 [28])

Diğer canlılarla karşılaştırıldığında insan, benmerkezci bir türdür. Bu bağlamda insan çevreyi ve dünyayı kendi algısına ve dünya görüşüne göre şekillendirmektedir. Toplumsal cinsiyet de insanlara toplumun verdiği cinsiyet rolleridir. Belki de toplumdaki birçok insan, bir kadının bedenine bakarak onu sadece arzu nesnesi bir kadın olarak görebilir. Zaten çoğu popüler kültür araştırmasında kadın bedeni erkeklerin arzularını baştan çıkaran şekilde betimlenmektedir [5]. Bu bilgiler ışığında çizgi romanlarda resmedilen ve grafikleşen bu kadın imgeleri, çă̆ın getirdiği koşullar, kadın hakları ve feminizmin getirdiği politikalarla birlikte değişim gösterecektir. Çağdaş çizgi romanlarda yaratılan kadın karakterler, daha doğru bir 
yaklaşımla ele alındıkça toplumsal cinsiyet algısının salt çizgi roman alanında değil her alanda kırılmasına katkı sağlayacaktır.

\section{5. ÇİZGI ROMANLARDA TOPLUMSAL CINSIYYET: KADIN BEDENI VE TEMSİL SORUNU (GENDER IN COMICS: WOMAN BODY AND REPRESENTATION PROBLEM)}

Günümüzde çizgi roman, yavaş yavaş hem bilim alanı olarak hem de popüler kültür araştırma alanı olarak kendini temsil etme konusunda umut verici bir keşif alanı hâline gelmektedir. Fakat bu büyüyen araştırma alanı içerisinde, cinsiyet araştırmaları büyük ölçüde yeterli değildir. Ya da açıkça ifade etmek gerekirse; çizgi roman çalışmalarındaki toplumsal cinsiyet tartışmaları birçok yönden hâlâ çok sınırlıdır. Hatfield, çizgi roman dünyasında "uzun süredir devam eden eril ön yargı" [21] ve popüler kültür denemecisi Douglas Wolk tarafından, çizgi romandaki kadınların genellikle çoğu kişice "en ağır bomba etkisi yaratan klişeler" olarak sunulduğunu savunmaktadır [36] . Çünkü kadınlar tarafından yaratılan çizgi romanlardaki grafik anlatılar cinsiyet ayrımcılığından dolayı görmezden gelinmiştir. Bu yüzden başlangıcından günümüze çizgi romanlar bir erkeğin dünyasının yansıtıldığı bir mecra olarak gösterilmiştir.

Temmuz 2004'te New York Times Dergisi, yeni bir edebi form olarak bahsettiği grafik romanlarla ilgili bir kapak hikayesi yayınlamıştır. "Çizgi romanlar şimdilerde yeni bir saygınlığın tadını çıkarıyor, çünkü çizgi romanlar, kitlelere hitap eden, güvenilir, yerel bir form olan romanlardır. Ve bu makalede dört erkeğin ismi geçse de fotoğraflarda ikisi kadın olmak üzere yedi kişi görülmektedir" [10]. Bu olayda da görüldüğü üzere toplumsal cinsiyet yargılarına dayanarak kadınların cinsiyet temsilinin kabul edilebilirliği hâlâ istismar edilmektedir. Judith Butler bu durum ile ilgili şunları söylemiştir: Kadınların yaşadığı temsil sorunu politik bireyler olarak görünebilirlik özelliği kazandırmayı amaçlamaktadır ve tüm bunların yanı sıra kilit özne sorumluluğunu üstlenen kadınlar, bir grup olarak gerçek ya da çarpıtılmış bilgilerin kullanıldığı dilin yalanlarına maruz kalan kişilerdir [7]. Dolayısıyla feminist kuramların üzerinden çizgi romanlarda, kadın karakterleri bir bütün olarak ya da gerektiği kadar savunan ve temsil eden bir lisanın geliştirilmesi, ister bir çizgi roman çizeri olarak isterse bir grafik anlatısı olarak kadınların görünürlüğünü sağlamak açısından önemlidir. Böylece toplumsal cinsiyet ayrımı ortadan kalkarak, erkek ya da kadın her ikisininde aynı varlıklar olduğu anlaşılacak ve her alanda cinsiyetleri üstünleştirme çabası sona erecektir.

Bir kimlik olarak kadın "siyasallaşmak, temsile kavuşmak için 'özne'olmak gerekliliğinin bilinciyle cinsel kimliğini kabul e[tmeli], ama ona öğretilen biçimde kucakla[mamalıdır]" [33]. Geçmişte kadın çizerlerin çizgi roman dünyasında adını dahi kullanmadığı düşünülürse cinsel kimliğin kabulü çok önemli bir durumdur. Özellikle erken dönem çizgi romanlara cinsiyet temsili olarak bakıldığında, erkeklerin ve kadınların resmedilmesi farklılık gösterir. Genç kadınlar hep güzeldir, erkekler de grotesk ${ }^{1}$ yapıdadır. Bu eğilim 20. yüzyıla doğru değişim göstererek cinsiyet açısından; komik görünümlü erkekler komik görünümlü kadınlarla, gerçekçi görünümlü erkekler gerçekçi görünümlü kadınlarla uyumlu bir şekilde çizilmiştir. Örneğin; Görüntü 3 ve 4'de görüldüğü üzere Temel Reis ile Safinaz ve Batman ile Catwoman bu duruma çok iyi birer örnektir (Görüntü 3). Temel Reis ile Safinaz daha komik, eğlenceli bir karakter olarak birbirini tamamlamakta, Batman ve

\footnotetext{
Köken olarak Fransızcadan gelen Groteks kelimesi, gotik anlamında kullanılan grotesque sözcüğünden yaygınıık kazanmıştır. Örneğin karikatür sanatı, grotesk anlayışa ve çizimlere sahip bir sanat dalıdır [23].
} 
Cat Woman ise yakışıklı ve güzel bir yapıda çizilmişlerdir (Görüntü 4). John Stuart Mill'inde belirttiği üzere karakterlerde yansıtılan bu farkın, doğuştan gelen biyolojik ayrılıklardan dolayı cinsler arasında ikincil bir konum oluşturduğu ifade edilmiştir [17].

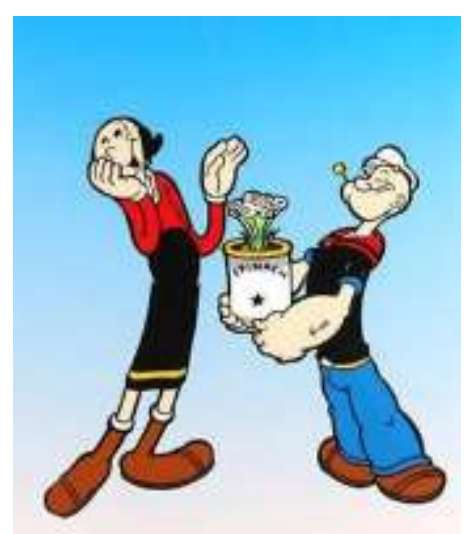

Görüntü 3. Temel Reis ve Safinaz, [14]

(Image 3. Popoye and Olive, [14])

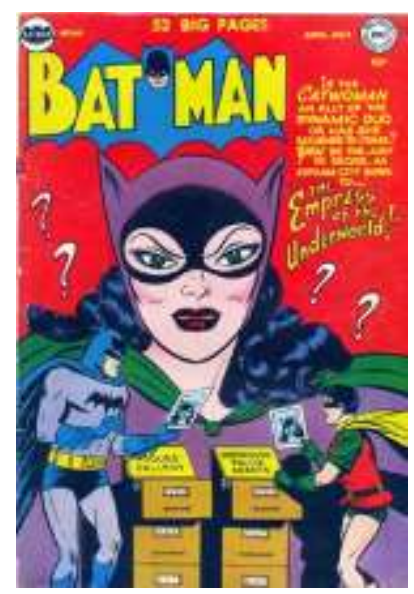

Görüntü 4. Whitney Ellsworth, Batman \#65 July, 1951 [12]

(Image 4. Whitney Ellsworth, Batman \#65 July, 1951 [12])

Çizgi roman ve cinsiyet hakkında en bilinen çizer ve araştırmacılardan biri de Trina Robbins'tir. Çünkü Robbins, kadın karakterlerin ve kadın bedenlerinin temsil edilme şeklinin derinlemesine teorik okumalarla araştırılmasını sağlamıştır. İster erkek bir birey de olsun ister kadın, toplumsal hayatta yüklenilen kimlik algısı, cinsiyet temsilinin evrensel ve değişmez bir kalıpmış gibi gösterilmesini sağlamaktadır. Fakat çizgi romanlarda cinsiyet temsili birçok açıdan değişiklik göstermektedir. Mell Gibson 'Gender and Comics/Cinsiyet ve Çizgi Roman' adlı makalesinde bu durumu şöyle açıklamıştır: "birincisi, çizgi roman içindeki temsil türe göre değişen bir şey; ikincisi, cinsiyet ve izleyiciler, yine; tarihsel döneme, coğrafi konuma ve türe göre değişir; sonunda, yaratıcılar ve cinsiyet"e göre demiştir [18]. Kadınların çizgi romanlarda cinsiyet temsili üzerine çalışan bir diğer isim ise Hillary chute'dır. Chute göre; Çizgi romanların sadece kadın bedenlerini temsil etmediğini, fakat bu bedenlerin temsil ettiği kadınlar tarafından çizilen kadın bedenlerinin, temsil sorusuna yeni risk unsurları ve olası komplikasyonlar eklenebileceğini söylemiştir. Bu unsurlardan biri cinsiyetle ilgili yaşanan 'travmalar' diğeri de 'sansürdür'. Örneğin 
kadınların; çocukluk, gençlik yıllarında yaşadığı travmalar ya da kadın bir çizerin eserine uygulanan cinsiyetçilik yaklaşımlarıyla sansürlenmesi olarak düşünülebilir. Bu yüzden chute kişisel olarak yaşanan travmatik deneyimleri; etik ve temsil etme riski ile ilişkilendirmiştir. Ve kitabında araştırdığı beş çizer kadının 'Aline Komminsky-Crumb, Phobe Glockner, Lynda Barry, Marjane Satrapi ve Alison Bechdel' temsil riskine maruz kalacağını savunmaktadır. Sonuç olarak; kadın bedeninin bir cinsiyet olarak temsili, baskıcı ve pornografik yapılarla karşılaşarak çizgi roman sektörü tarafından nesneleştirilmeye devam edecektir. Bu açıdan makalenin metodolojisinin anlaşılabilmesi için kültürel yapıların dışında cinsiyet temsillerinin neden nesneleştirildiğinin araştırılması da gerekmektedir.

\section{NESNELEŞTIRME VE PORNOGRAFİ (OBJECTIFICATION AND PORNOGRAPHY)}

Nesneleştirme, kadınların temsilini ve cinselliği ifade eden her konuda kadın bedeninin kaçınılmaz olarak pornografik unsurlara maruz kalmasıdır. Bu bağlamda kadınlar, sanattan tasarıma, sinemadan çizgi romana pek çok alanda bir kimlik olarak nesneleştirilmektedirler. "Mevzu bahis kadınların görsel imgeleri ve varlıkları olduğunda, soyut bir obje gibi arzulanan kadın vücutları hakiki bir varlığa dönüşür, vücut sadece cinselliğin meskeni ya da heveslerin odak noktasıdır" [2]. Bu araştırma makalesi kapsamında kadınların çizgi romandaki tarihi ve diğer görsel medya formlarındaki temsili incelendiğinde "kadın tasvirinin büyük ölçüde erkek bakışları için yaratıldığı, çünkü çizgi romanların okuyucusunun ağırlıklı olarak erkek olduğu düşünülmektedir. Böylece kadın bedeni nesneleştirilir ve çizgi roman panellerinin dahilinde bir arzu nesnesi olarak tüketilir, ancak asla kadınların arzularını göstermelerine izin verilmez" [22]. Nitekim Arzu düzeni "açıkça söylemek gerekirse bende eksik olan bir şeyi başkasında aramak demektir" [3]. "Bir bilince sahip olmadan davranan kadın hem erkeklerce hem de kadınlar tarafından her zaman bir izlence ve takip altındadır" [11].

Kadınlar, sadece erkekler tarafindan arzulanarak nesneleştirilmemekte hem cinsleri tarafından da gözetim altına alınmaktadırlar. Böylece nesneleştirmek baskıcı bir yapıya bürünmektedir. $\quad$ kadar ki kadınlar, vücutlarını diğer kadınların/erkeklerin beğenmesi için; spor ve diyet yaparlar, kuaföre giderler, estetik operasyon yaptırırlar. Bu açıdan Sandra Bartsky, "cinsel nesneleşmenin iki kişiyi içerdiğini savunarak, itiraz eden ve itiraz edilen kişiler" olarak belirtmiş, "gözlemci ve gözlenenin aynı kişiler olabileceğini söylemiştir" [4]. Kadınlar çizgi romanlarda genellikle bedenleri, fiziki özellikleri ya da kıyafetleri kullanılarak nesneleştirilmektedirler. Bu açıdan "Kadınların cinselliği, güzelliği ve çekiciliği birleştirmek için kullanılan bacaklar, gözler, ağız ve göğüsler ile tanımlanır" [22]. Özellikle uzun saçlı kadınlar cinselliğin gücüyle sembolize edilmektedir.

Ana akım çizgi romanlarda anlatılardan daha fazla odaklanılarak kadınların bedenleri fetişleşmeye meyillidir, aktif bir bütünden ziyade parçalar olarak gösterilirler ve tipik olarak hem göğüslerini hem de arka uçlarını dahi gösteren bedensel olarak olanaksız konumlarda çizilirler. Bedenleri katlanmış, yamulmuş ve mübalağalıdır. Modern çizgi roman kapaklarının bir incelemesi dâhi, kadınları kameradan uzağa çizilen yüzlerini ortaya koyuyor, bakışları okuyucuyla güçlü bir şekilde yüz yüze gelen erkek kahramanlar ile ilgili olarak pasifliklerini ortaya koyuyor [32].

Böylece çizgi romanlarda kadınlar nesneleştirilirken beden olarak resmediliyor, başkalarının zevkleri ve yararına maddeselleştirilmektedirler. Zaten şu anki şekliyle çizgi romanlarda 
resmedilen ve gösterilmeye çalışılan süper kahramanların asıl fonksiyonları erkeklik ikonları oluşturmaktır [34]. Çoğu çizgi romanda ise; erkek bedeni gücü sembolize ederken, kadın bedeni pornografik unsurlara maruz kalmaktadır. Yine çizgi romanlarda kadınların nesneleştirilmesini en iyi anlatan bireyler kadın çizgi roman sanatçılarıdır. Kadınlar tarafından yazılan ve çizilen otobiyografik eserler kendilerini nasıl gördüklerinin somut temsili olur. Örneğin; "Amerikalı sanatçı Phoebe Gloeckner çocukluk döneminde yaşanan çocuk istismarlarına karşı kendi otobiyografik çizgi romanında annesinin erkek arkadaşlarıyla olan ilişkisini, bir genç olarak yaşadığı sıkıntıları anlatmıştır" [10] (Görüntü 5).
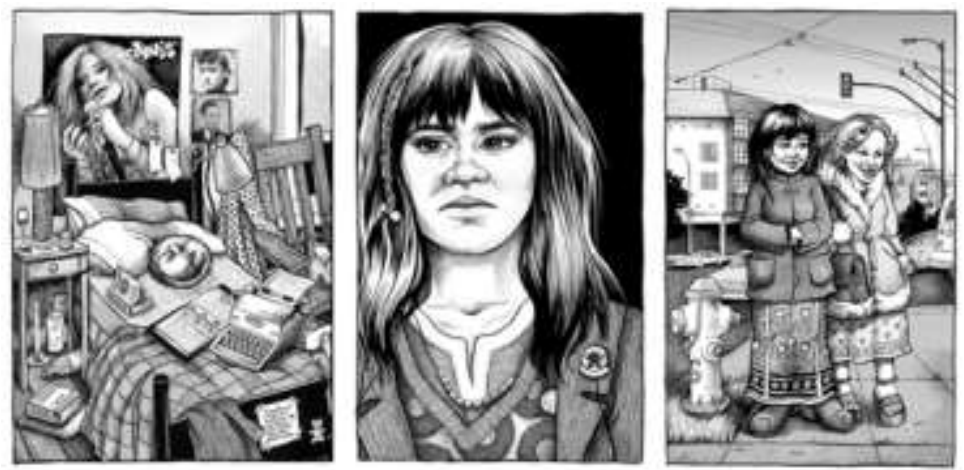

Görüntü 5. Phoebe Gloeckner, The diary of teenage girl, 2002 [19]

(Image 5. Phoebe Gloeckner, The diary of teenage girl, 2002 [19])

Çizgi romanda nesneleştirme, sadece insan figürlerinde değil hayvan figürlerinde de görülmektedir. Komik hayvan çizgi romanlarında, hem erkek hem de dişi hayvanlar aynı çizgi romanda ve genellikle sevimli bir tarzda çizilmiştir. Belki de hayvan çizgi romanının çocuklar için olması nedeniyle, erkek çizerler, dişi hayvanları göğüslerle çizmek yerine, küçük fiziksel özellikleri abartmak suretiyle onları dişi olarak tanımlamıştır. Böylece kirpikler ikincil cinsiyet özellikleri hâline gelmiştir (Görüntü 6). Minnie Mouse ve Petunia Pig'e uzun, abartılı kirpikler verilmiş, ama Mickey ve Porky'nin hiç kirpiyi yoktur (Görüntü 7) [29].

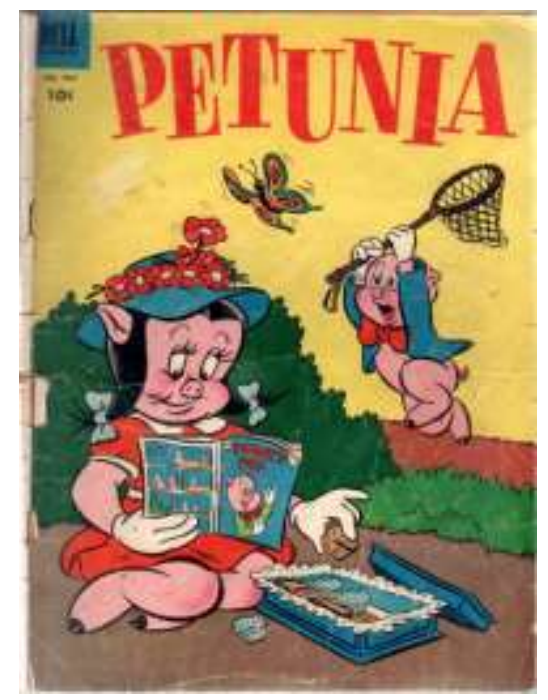

Görüntü 6. Warner Bross, Porky ve Pentunia Pig, 1976 [6] (Image 6. Warner Bross, Porky and Pentunia Pig, 1976 [6]) 


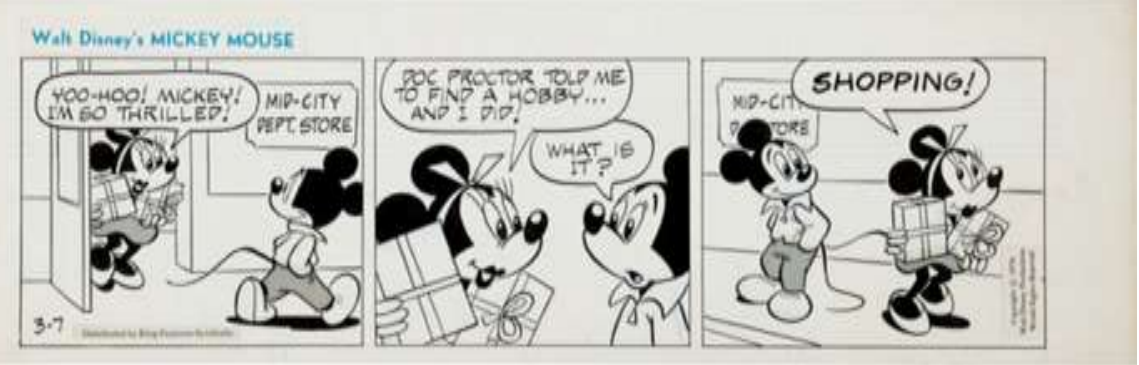

Görüntü 7. King Features, Minnie Mouse ve Mickey Mouse, 1978 [15] (Image 7. King Features, Minnie Mouse and Mickey Mouse, 1978 [15])

Ayrıca çoğu çizgi romana bakıldığında kadın ve erkek çizerler arasında, çizim yaparken her birinin kendine özgü farklı tarzları olduğu görülmektedir. Bir çizgi roman okunduğunda onun erkek bir çizere mi ait, yoksa kadın bir çizere mi ait olduğu kolaylıkla anlaşılabilmektedir. Çünkü kadın çizerlerin, çizimlerinde kadınsı bir duyarlılık ve stil mevcuttur. Ancak bir kadın, kız gibi yazar ve çizer. Erkek çizerlerin, çizimlerinde ise; heteroseksüel bir yapıdan kaynaklı küfürler, kadınların nesneleştirilmesi ve pornografi unsurları vardır. Kadın ve erkek süper kahramanların anlatıldığı hikayelerin konularına bakıldığında, hep bir dünyayı kurtarma olgusu ve aşk üçgeni bulunmaktadır. Gerek çizgi romanların satması gerekse kadın bedeninin ilgi çekici olarak çizgi roman pazarında sunulması; kadın bedeninin nesneleştirildiğinin göstergelerindendir (Görüntü 8). Bazen kadın süper kahramanların aşırı derece seksi bir şekilde çizilmiş olması, onların diğer özelliklerinin geride kalmasını sağlamaktadır. Frederic Wertham'ın 1954'teki Masumun Baştan Çıkarılması'ndan, 1999'da Gail Simone tarafından başlatılan Buzdolaplarında Kadın Hareketi'ne kadar, çizgi roman okurları, kadınların canlandırıldığı çeşitli durumları incelemişlerdir. Kadınların olumsuz davranışlar sergilerken resmedildiği ya da nesneleştirildiği çoğu çizgi romanlar da sansür uygulanarak piyasadan kaldırılmıştır.

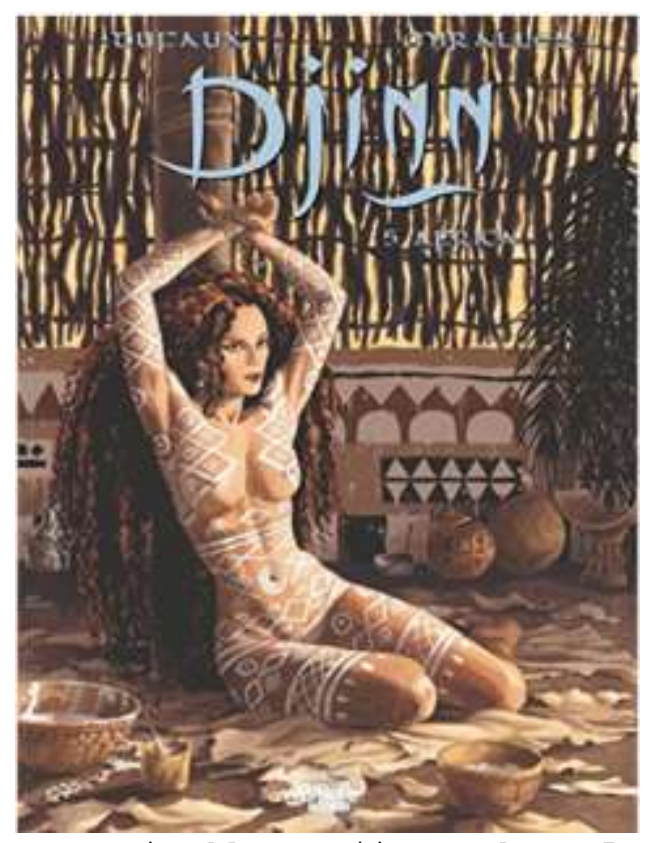

Görüntü 8. Ana Miralles, Djinn volume 5, 2016 [27]

(Image 8. Ana Miralles, Djinn volume 5, 2016 [27]) 


\begin{abstract}
Ayrıca "kadın karakterlerin erkek kahraman merkezli çizgi romanlardaki temel işlevlerinden biri 'heteroseksüel bir gösteren' olarak varolmalarıdır" [34]. Bu nedenle kadınların yan ve düşük karakter olarak yansıtıldığı çizgi romanlarda genellikle öldürülme, şiddete maruz kalma, sakat bırakılma gibi eylemler ağırlıklıdır. İşte bu duruma bir tepki olarak 1999 yllinda Gail Simone WIR: Women in Refrigators Syndrome/Buzdolaplarında Kadınlar Sendromu adlı hareketi ve web sitesini kurmuştur. Aslında bu gibi durumlardan anlaşılacağı üzere sadece erkek karakterlerin hikayesini daha iyi göstermek ve ilerletmek için kadın karakterlere zarar verilmesi kadınların nesneleştirilmesinin bir başka versiyonudur. Örneğin; Alexandra DeWitt sevgilisi Green Lantern'in öncü hasımı olan Major Force'ca boğazı kesilerek buzdolabına koyulmuş, bu durum çizgi roman piyasasında (WIR) adlı akımın doğmasını sağlamıştır (Görüntü 9).
\end{abstract}

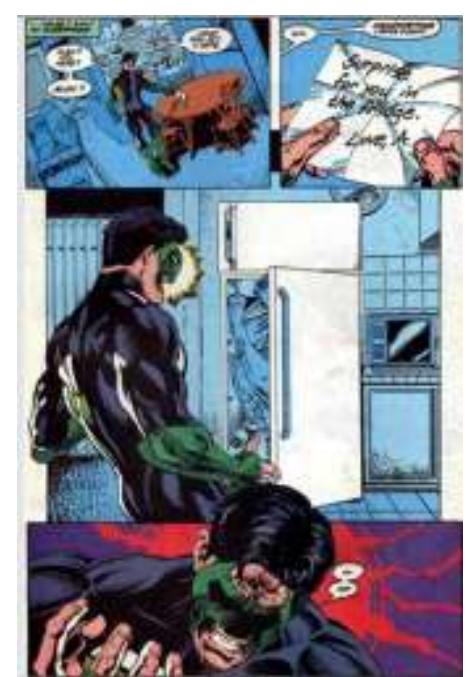

Görüntü 9. Gail Simone, Women in Refrigators Syndrome, Green Lantern $\# 54,1994$ [31]

(Image 9. Gail Simone, Women in Refrigators Syndrome, Green Lantern \#54, 1994 [31])

1990'lı yıllarda çizgi komanlarda kadınların nesneleştirilmesindeki abartılar o kadar fazlaydı ki bazı kadın okurlar, bu durumu gerçek hayatına yansıtmıştır. Hakiki ve fantastik arasındaki ayrımda var olan süper modeller, güzellik çubuğunu çoğu kadın için ulaşılmaz bir düzeye yükseltti ve erkeklerin bir eş bulma çabalarını imkansızlaştırdı. "İnsanlar bu kadınların genetik anamoliler olduğunu, fantazilerin ya da rüyaların hayata geçtiğini, ideal harikulade canlıların resimlerini yarattıklarını unutmuşlardı" [25]. Bu idealize yaratılmış kadın bedenlerinden yola çıkarak çizgi roman dünyasında da kadının bedeni belli bir kalıba sokularak ideal kadın yaratıldı. Böylelikle çizgi roman evreninde "kadın-erkek bedeninin metalaştırılması perçinlenmiştir" [9]. Fakat unutulmamalıdır ki kadınların çizgi romanlarda nesneleştirilmesi kadar erkekler de aynı sorunlarla karşılaşmıştır. "Bilindiği gibi, çizgi romanlardaki kahramanların kaslı ve erkeksi görünümü, karakterin agresif potansiyeline işaret etmesi açısından eril bir gösterge" olarak değerlendirilebilir" [34]. Böylece şişman ya da zayıf bir erkek kahraman yerine, kaslı ve seksi bir erkek kahramanın yaratılması cinsiyetçi bir anlatım olduğunu ifade etmektedir. Bazı çizgi romanlarda da kadın karakterler sadece dış görünüşleriyle değil davranışlarıylada nesneleştirilmişlerdir. Örneğin; Superman ve Batman denilince ilk akla gelen kadınlar Louis Lane ve Batwoman'dır. İki 
güçlü erkek ve iki güzel kurtarılmayı bekleyen kadın figürü için hep çizgi romanın sonu evlilik olarak yorumlanmaktadır. Bu yüzden görsel anlamda Batwoman ve Lois Lane nesneleştirilmese de evlenmeye olan ilgilerinden dolayı nesneleştirilmeye maruz kalmışlardır. Kadınların çizgi romanlarda pornografik unsurlarla nesneleştirilmesi, kadın imajının gerek bedenleşmesine gerekse erkeklerin bakışlarına maruz kalarak toplumdaki çoğu kişinin onu ulaşmasını sağlayarak toplumsal cinsiyet algısının etkisinde ideal bir kadın tablosu yaratmıştır. Bu açıdan kadınlar nesneleştirildikleri bir ortamda 'neden çizgi roman okusunlar ki?' gibi soruların cevabı araştırma kapsamında değerlendirilebilir.

\section{7. ÇİZGI ROMAN OKUYUCUSU OLARAK KADIN (WOMAN AS A COMIC NOVEL READER)}

Günümüzde çizgi romanlar sadece entellektüel erkeklerin ve erkek çocuklarının sevdiği bir popüler kültür ürünü olarak karşımıza çıkmaktadır. Ya da çizgi romanların öncelikle erkek okuyucu için tasarlandığıyla ilgili bir algı söz konusudur. Çünkü; geçmişte "tefrika hâlinde yayımlanan çizgi romanların baş kahramanı erkekler oluyor, hikayeler erkek karakterin hayatını yansıtıyor ve kadın hikayesine yer veren çizgi roman örneklerine çok az rastlanıyordu" [1]. Doğal olarak yaratılan kadın karakterler ya aptal sarışın ya da güçlü ve erkeksi bir kadın olarak resmedilmekteydi. Ayrıca çizgi romanlarda; "Batman, Superman, Örümcek Adam gibi erkek karakterlere yer verilirken, kadın karakterlere Supergirl, Power Girl, Marvel Girl, Invisible Girl isimleri verilmiş, Wonder Woman dışında 'kadın' olarak nitelendirilen bir karakter bulunmamaktadır" [25]. Daha sonra 'Cat Woman' da kadın olarak isimlendirilen karakterler arasına girmiştir. Dolayısıyla bu araştırmada, kadınların yer almadığı ya da kadınlara yönelik toplumsal cinsiyet yaklaşımlarının uygulandığı bir çizgi romanı bir kadın nasıl alıp okuyabilir? sorusu üzerine çalışma geliştirilmiştir.

Douglas Wolk, çizgi roman alan ve okuyan kadınların, erkek çizgi roman hayranları tarafından cinsiyetlerini yanlış bir şekilde sergilediklerini fark etmiştir. Çizgi romanların sinir bozucu erkek dünyasını temsil ettiğini söyleyen Wolk'a göre; kadınlar o dünyadan dışlanmaktadır. Wolk çizgi roman okuyan kadınlar için şöyle bir açıklamada bulunmuştur: "bir çizgi roman dükkanındaki çizgi roman okuyan kadın bir anormalliktir... Ya kadınlığını sergileyemiyor, ya da yanlış çizgi roman okuması yapıyor"dur [36]. Belki de çizgi roman adına temel sorun her iki cinsiyetten; yetişkin, genç ve çocukların birer okuyucu olarak neler istediklerine bakılmamasıdır. Bir çizgi roman okuru, genellikle çizgi romanlarda; anlatısı güçlü iyi hikayeler, ilginç karakter gelişimi ve güçlü sanat eseri niteliği gibi özelliklerle ilgilenmektedir. Kadın çizgi roman okuru açısından bakıldığında ise; her zaman ezilen ve toplumsal cinsiyet yargılarıyla nesneleştirilen kadın figürü yerine, gerçek hayattan farklı olarak çizgi romanlarda günlük hayatta karşılaşabileceğimiz daha kadınların ön planda olduğu bir çizgi roman anlayışı geliştirilmelidir. Yani kadınlar, artık ikinci plana atılmak istememektedirler. Örneğin; "olga Mesmer adında bir kadın, diğer süper kahramanlar arasında X-RAY gözlere sahip ilk süper kahramanlardandır" [11]. Fakat daha sonra Olga Mesmerin hikayesi Superman'e çok benzediği için yayından kaldırılmıştır. Yine Supergirl, Action Comics no:252'de (Mayıs 1959) Süpermen'in kuzeniydi. "Supergirl'in ilk görünümünde, Süpermen 'Büyük ağabey gibi seninle ilgileneceğim' diyerek ona güvence verir, fakat Supergirl'in zorlu güçlerine sahip bir kimsenin birine bakması gerekli değildir" [24]. Onun kız ya da kadın olması bir erkek tarafından korunmaya ihtiyacı olacağı anlamına gelmemelidir. İkinci Dünya savaşı 
sırasında özellikle Amerika'da vatansever süper kahramanların, hem erkek hem de kadın olarak ortaya çıkması çizgi roman okuyucularının dikkatini çekmiştir. Hep erkek süper kahramanların olduğu bir dünyada 1942 yılında DC yayınevinin yarattığı Wonder Woman karakteri Amerikan bayrağını hatırlatan kıyafetiyle büyük ilgi görmüştür. Ve Wonder Woman'la ilgili; savaştaki erkeklerin daha iyi konsantre olmaları ya da geriye kalan kadınların milli duygularını artırmak için böyle bir karakterin yaratıldığı iddaaları ortaya atılmıştır. Bu dönemden sonra ister kadın olsun ister erkek çizgi roman okurlarının ilgisiyle; DC, 1943'te 'Liberta Belle'yi, Marvel ise, 'Captain America'yı yaratmıştır (Görüntü 10).

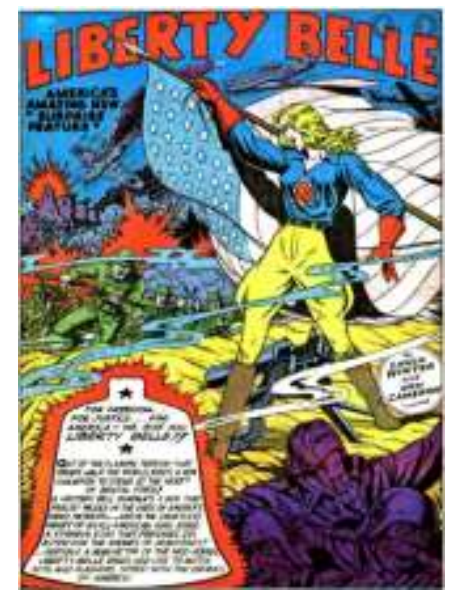

Görüntü 10. Don Cameron ve Chuck Winter, Liberte Belle, 1942 [8] (Image 10. Don Cameron and Chuck Winter, Liberte Belle, 1942 [8])

Erkek okurlar, özellikle milyonlarca ABD'li asker arasında, yeni süper kahraman ve kadın suçlu savaşç serisini giderek daha popüler hâle getirdi. Bu durum modern koleksiyoncuların ironik bir şekilde "iyi kız sanatı" olarak adlandırdığı yeni bir çizgi roman tarzını ortaya çıkardı. "Çizgi roman tarihçisi Ron Goulart sözleriyle; çizgi roman, kızları izlemenin bir yolunu sunmaktadır. Her geçen yıl, kadın karakterlerin kıyafetleri daha cesur bulunuyor, pozları daha kışkırtıcı ve karşılaşmaları giderek şehvetıi oluyordu" [24]. Dünya'da erkek egemen bir süper kahraman furyası hakimken, Türkiye'de de kadın ve çizgi roman adına değişen pek bir şey yoktur. Zaten Türkiye'de üretilen kadın karakter sayısı yok denecek kadar azdır. Bu yüzden çizgi roman yayıncıları ile çizgi roman okuyucuları arasındaki bağlantı geliştirilmeli, heteroseksüel algı yıkılmalıdır. Ayrıca Will Eisner da, çizgi roman okuyucusu ve yaratıcısı arasında karmaşık bir ilişki olduğunu doğrulamıştır. Bu bağlamda çizgi roman okurları ve yazarlarca ortak bir çalışma yürütülemezse çizgi romanların bir işleve sahip olmayacağını iddia ederek: "Tüm çizgi romanlar sıralı olarak sanatçı ve okuyucunun sözsüz işbirliğine dayanıyor... Gerçekten de, bu çok gönüllü işbirliği çizgi romana özgü, sanatçı ve izleyici arasındaki sözleşmenin temelini oluşturduğunu" dile getirmiştir [13]

Erkek yaratıcılar ve yayıncılar salt erkek egemen ve hetoroseksist çizgi roman üretmeyi kadın okurların sayısını arttırmak ve kadınlara daha saygılı davranmak adına bu yaklaşımları bırakmak zorundadırlar. Kadın okurların, çizgi romana ilgisi ancak onların kimlik ve beden olarak nesneleştirilmediklerinde gerçekleşecektir. Bu nedenle, McCloud okuyucu ve çizgi roman arasındaki ilişkiyi şöyle açıklamıştır: "Çizgi roman sanatçısının kağıda döktüğü her eylem, sessiz bir ortağın, yardım ve yataklığında gerçekleşir. Bu eylemin eşit suç ortaklığını yapana da OKUR denir" [26]. Kadınların birer okur 
olarak daha fazla çizgi roman disiplinine ilgisini artırmak için 'çizgi roman tarihinin' ve kadın çizgi roman sanatçılarının kadınlar açısından daha detaylı incelenmesi gerekmektedir. Örneğin; Amerika çizgi roman alanındaki kadınların tarihini araştırmak için 2014 yılında yayınlanan 'She Makes Comics' adlı bir belgesel film çekmiştir. Film, kadınların çizgi romana katkısını çizgi roman tarihi açısından ele almaktadır. Tüm bu bilgilerden yola çıkarak; kadınların çizgi romana suç ortağı olabilmesi için yayıncılara ve sanatçılara, yazarlara büyük bir görev düşmektedir.

\section{ANKET ÇALIŞMASI VE BULGULAR (SURVEY STUDY AND FINDINGS)}

Çizgi romanlarda kadın ve erkek karakterlere yönelik yapılan nesneleştirme ve pornografi unsurlarının değerlendirilebilmesi için yapılan bu anket araştırmasında, makalenin amaçlarının gerçekleştirilebilmesi adına çalışmanın ölçülebilir yanlarının gözlenmesi hedeflenmiştir. Anket yaş aralığı, 15-60 yaş olarak belirlenip Giresun'a bağlı Görele ilçesinde liselerde okuyan bazı genç öğrencilerden, İstanbul Çizgi Roman Okurları Dernek Üyeleri ve Görele Güzel Sanatlar Fakültesi Grafik Tasarımı Bölümü öğrencilerinden ankete katılım sağlamalarında yardım alınmıştır. Makale süreci sırasında yaşanan Covid-19 salgını sebebiyle lise gibi okullara olan anket dağıtım planı programdan çıkarılmıştır. Anket, Google Forms üzerinden düzenlenmiş olup 150 kişilik katılım sağlanmıştır. 22 sorudan oluşan ankete, 58.7 kadın ve 41.3 erkek okuyucu katılmıştır. Bu kadın ve erkek katılımcıların ise yaş aralığı; \%20.3'ünü 15-20 yaş, \%47.3'ünü 20-35 yaş, ⒚6'sını 40-50 yaş, \%12.2'sini de 50-60 yaş oluşturmaktadır. Katılımcılar tarafından "Ne sıklıkla çizgi roman okuyorsunuz sorusuna?" $\div 67.3$ oranında her gün, 12 oranında iki haftada bir, 10 oranında ayda bir, o10 oranında yılda bir, \%0.7 oranında da asla cevabı verilmiştir. Bu durum ankete katılan çoğu katılımcının çizgi roman okumayı tercih ettiğini ya da sevdiğini göstermektedir. Ankette yer alan "Hangi tür çizgi roman okuyorsunuz?" sorusuna ise katılımcllar tarafindan $\% 62$ oranında "Marvel/DC ve çeşitli yayınevlerinin çizgi roman dergileri", \%30.7 oranında Grafik Roman ve $\frac{0}{7} .3$ oranında da Manga cevabı verilmiştir. Yukarıda yer alan ilk dört anket sorusu katılımcıları tanımaya yöneliktir. Ankette yer alan 5. soruda ise katılımcılara "Çizgi Romanlarda kadın karakterlerin ağırlıklı olmasını seviyor musunuz?" sorusu yöneltilerek 98 oranında evet o2 oranında hayır cevabı alınmıştır (Grafik 1). Ayrıca ankette 6. soru olarak katılımcılara "Çizgi Romanlarda erkek karakterlerin ağırlıklı olmasını seviyor musunuz?" sorusu yöneltilerek her iki cinsiyetin çizgi romanda görülme isteğinin ölçülmesi hedeflenmiştir. Katılımcilar tarafından bu soruya \%50.7 oranında evet, \%49.3 oranında hayır cevabı verilmiştir.

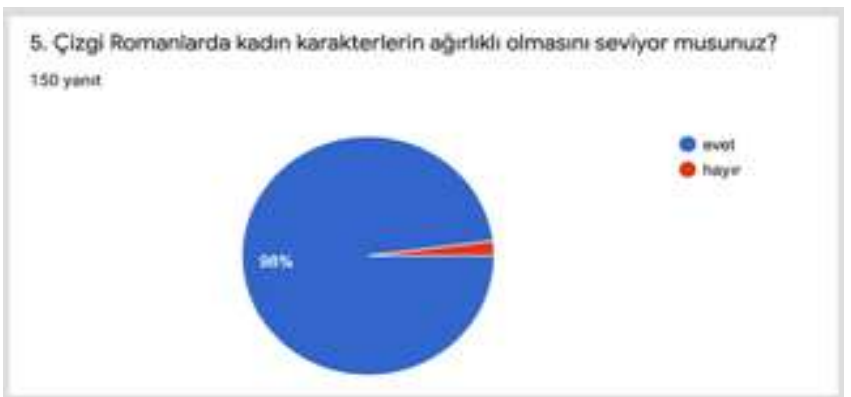

Grafik 1. Ankette yer alan 5. soru ve cevap oranları

(Graphic 1. 5th question and answer rates in the survey) 


\begin{abstract}
Anketin 7. sorusunda ise; makalenin de üstünde durulan konularından biri olan toplumsal cinsiyet yaklaşımı ele alınarak "Günümüz çizgi romanlarında toplumsal cinsiyet ayrımı yapıldığını düşünüyor musunuz?" sorusu katılımcılara yöneltilmiştir. Katılımcılar, \%94 oranında evet \%6 oranında hayır cevabını vererek çizgi romanlarda toplumsal cinsiyet ayrımı yapıldığını doğrulamışlardır (Grafik 2). Bu durum ankete katılanlar üzerinden yorumlanırsa, çizgi romanlarda sadece tek bir cinsiyet algısı üzerinden konunun ilerlemesi istenmemektedir şeklinde düşünülebilir.
\end{abstract}

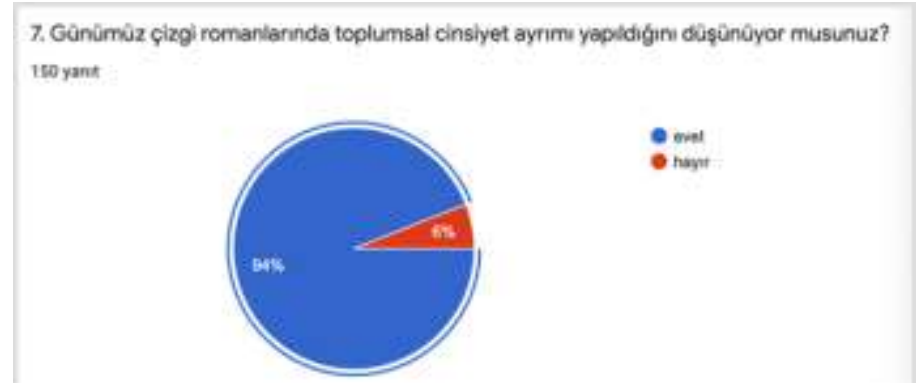

Grafik 2. Ankette yer alan 7. soru ve cevap oranları

(Graphic 2. The 7th question and answer rates in the survey)

Ankette 8. ve 9. sırada yer alan "Piyasada karşılaştığım çizgi romanlar cinsiyet temsili açısından beni yansıtmıyor" cümlesi kadın ve erkek katılımcılara ayrı ayrı yönlendirilmiştir. Bu bağlamda 58 oranında kadınlar piyasada yer alan çizgi romanların onları cinsiyet temsili açısından yansıtmadığını düşünmekte, \%42 oranında da kendilerini yansıttıklarını düşünmektedirler. Erkekler ise; 062 oranında hayır oyu kullanarak piyasada bulunan çizgi romanların cinsiyet temsili açısından onları yansıttığını, 응 oranında da yansıtmadığını düşünmektedirler (Grafik 3). Bu durum kadın katılımcıların cinsiyet temsili açısından çizgi romanları yeterli bulmadığını, erkek katılımcıların ise yeterli bulduğu bilgisini ortaya çıkarmaktadır.

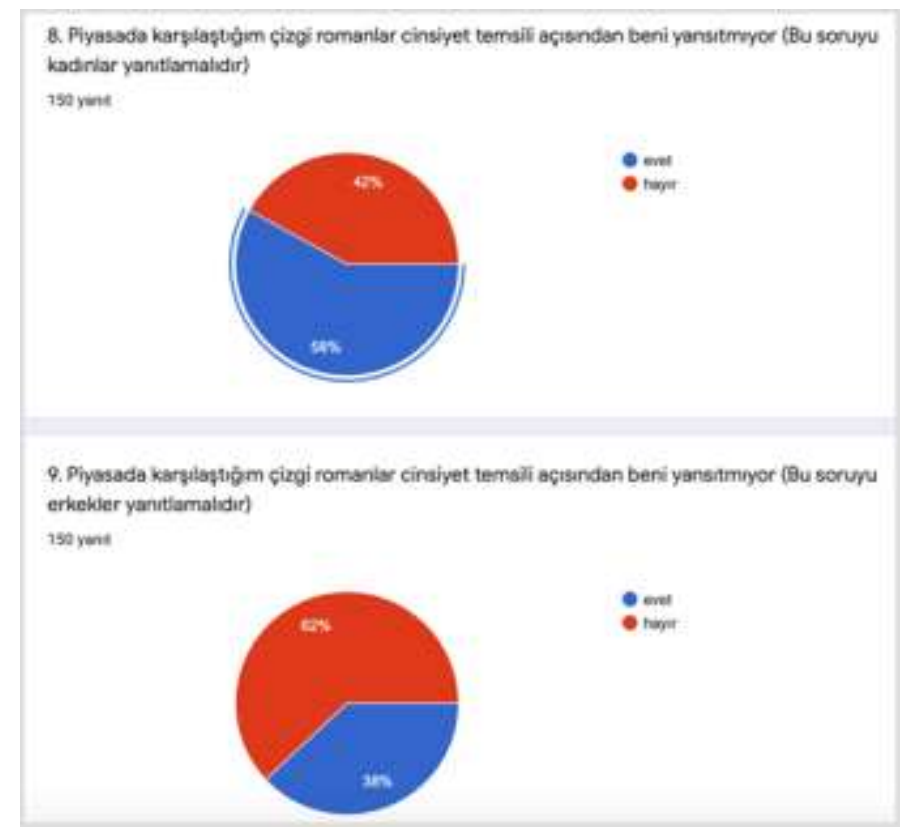

Grafik 3. Ankette yer alan 8. ve 9. soru ve cevap oranları

(Graphic 3. 8th and 9 th questions and answer rates in the survey) 


\begin{abstract}
Ankette yer alan 10., 11., 12., ve 13. sorular birbiriyle bağlantılı olarak çizgi romanlardaki karakterlere yapılan nesneleştirme yaklaşımıyla ilgilidir. Bu bağlamda ankette yer alan 10 . soruya yönelik "Çizgi romanlarda nesneleştirilmeyen kadın karakterlerin yaratılması çizgi roman okumaktan daha çok zevk almamı sağlıyor" ifadesine 97.3 oranında evet ⒉7 oranında hayır cevabı katılımcllar tarafından verilmiştir. Yine katılımcılara 11. soruda "Çizgi romanlarda kadın karakterlerin nesneleştirilmesine rastlıyor musunuz? Hangi çizgi roman boşluğa yazınız?" ifadesine katılımcıların çoğu "cat woman" cevabını vermiştir. Bu durum Cat Woman gibi popüler ve en bilindik çizgi roman kadın karakterlerinin okuyucularda nesneleştirme hissi uyandırdığını doğrulamaktadır. 12. soruda da katılımcılara "Çizgi romanlarda nesneleştirilmeyen erkek karakterlerin yaratılması çizgi roman okumaktan daha çok zevk almamı sağlıyor" ifadesi için katılımcılardan \%94 oranında evet, \%6 oranında hayır cevabı alınmıştır. Ankette yer alan 13. soru olan "Çizgi romanlarda erkek karakterlerin nesneleştirilmesine rastlıyor musunuz? Hangi çizgi roman boşluğa yazınız?" ifadesine yönelik ağırlıklı olarak Batman ve daha düşük oranda da Süperman, Kaptan Amerika, Savaşçı, Temel Reis, One Piece gibi cevaplar verilmiştir (Grafik 4).
\end{abstract}

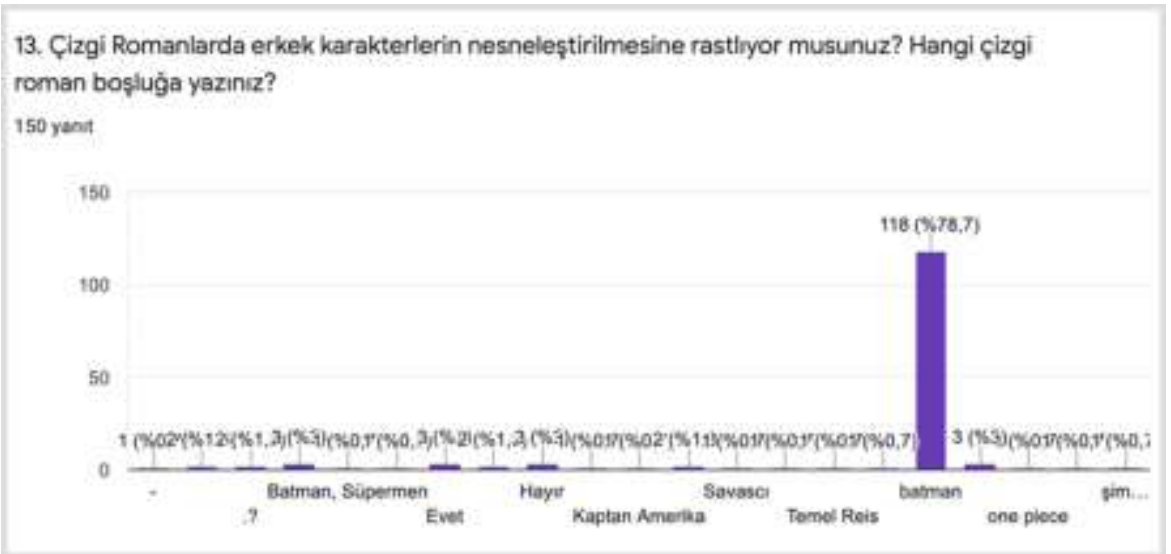

Grafik 4. Ankette yer alan 13. soru ve cevap oranları

(Graphic 4. The 13th question and answer rates in the survey)

Ankette yer alan 14. soru da ise katılımcllara "Piyasada bulunan çoğu çizgi romanın pornografi içerdiğine inanıyor musunuz?" ifadesi yöneltilerek 88 oranında evet, 12 oranında hayır cevabı alınmıştır. 15. soru da da "Çizgi Romanlar daha çok erkekler için mi yaratılıyor?" sorusuna yine katılımcılar tarafından :88 evet, 12 oranında hayır cevabı verilmiştir. Bu durum "piyasada çizgi romanların daha çok erkek okuyucu için yaratılıyor" algısının katılımcılar tarafından da doğrulamasını sağlamıştır. Ankette 16. soruda katılımcılara "Özel olarak kadın okur için yaratılmış çizgi romanlara rastlanıdınız mı?" ifadesi yönlendirilerek o86.7 oranında evet, \%13.3 oranında hayır cevabı alınmıştır. 17. soruda da katılımcılara "Kadın okura özel yaratılmış çizgi roman kitabı örneği veriniz?" ifadesi yönelendirilmiş ağırlıklı olarak Tina, Wonder Woman, Black Widow ve daha az oranlarda da Bayan Yanı, Prestij, Cat Woman, This One Summer, Ali Haru Ride gibi çizgi romanlar söylenmiştir (Grafik 5). 


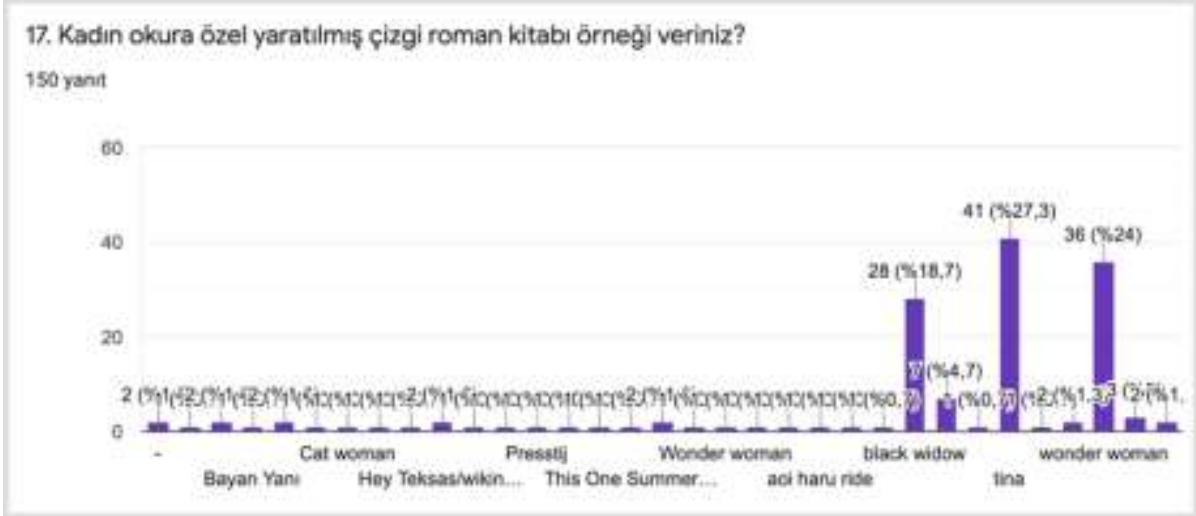

Grafik 5. Ankette yer alan 17. soru ve cevap oranları (Graphic 5. 17th question and answer rates in the survey)

Ankette yer alan 18. soruda ise "Özel olarak erkek okur için yaratılmış çizgi romanlara rastladınız mı?" sorusu katılımcılara yönlendirilerek \%87.3 oranında evet, ⒓7 oranında hayır cevabı alınmışır. Yine 19. soruda da katılımcılara "Erkek okura özel yaratılmış çizgi roman kitabı örneği veriniz?" ifadesi yönlendirilmiş ağırlıklı olarak Tommiks, Metal Batman, Süperman ve daha az oranda Hunter x Hunter, Full Metal Mentalist gibi cevaplar alınmıştır (Grafik $6)$.

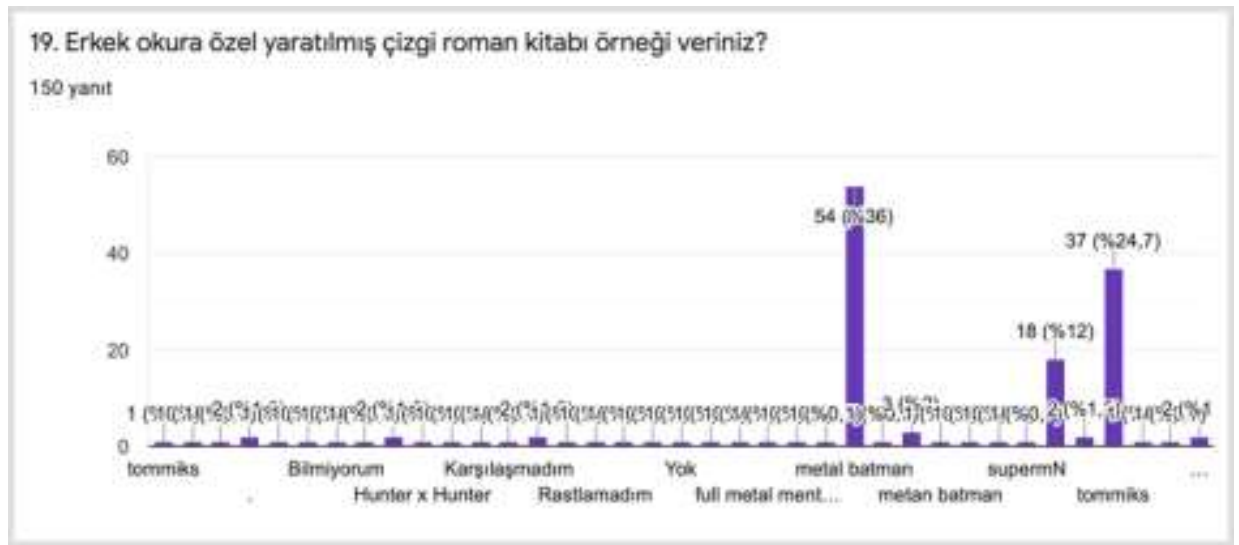

Grafik 6. Ankette yer alan 19. soru ve cevap oranları

(Graphic 6. The 19th question and answer rates in the survey)

Katılımcılara 20. soruda "Çizgi romanda yaratılan kadın karakterler daha çok erkek karakterin onu kurtarmasını bekleyen (muhtaç) rolde mi?" ifadesi yönlendirilmiş, ⒐ 5 oranında evet, ⒋7 oranında hayır cevabı alınmıştır. Fakat ardından 21 soruda "Güçlü kadın karakterlerin yaratıldığı çizgi romanlara rastladınız mı?" ifadesi yönlendirilmiş, 96.7 oranında evet ⒊3 oranında hayır cevabı alınmıştır. Bu iki sorudan da ortaya çıkan sonuç; katılımcıların çizgi romanlarda yer alan çoğu kadın karakteri erkek karakterlerin yanında gördüğü ve bazen de güçlü kadın karakterlere rastlayabildikleridir. Anketin 22. sorusunda ise; "Güçlü kadın karakterlerden oluşan çizgi roman örneği veriniz?" katılımcılara yönlendirilmiştir. Yanıtlar yine ağırlıklı olarak popüler bir karakter olan "Wonder Woman" ve daha az oranda Black Widow, Hela gibi cevaplar verilmiştir (Grafik 7). 


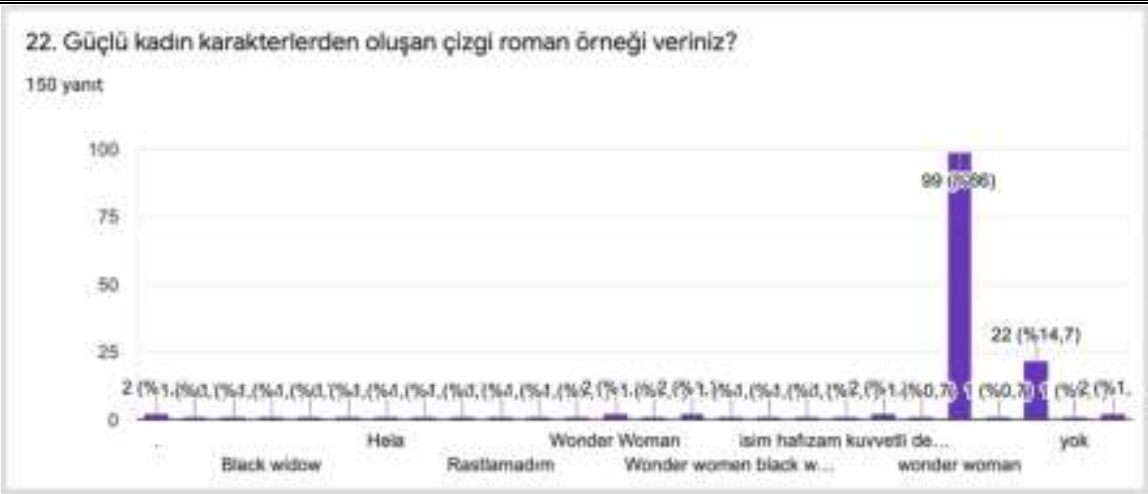

Grafik 7. Ankette yer alan 22. soru ve cevap oranları

(Graphic 7. The 22 nd question and answer rates in the survey)

Bu anket çalışmasının sonuçlarının Giresun ili Görele ilçesinde yaşayan lise öğrencileri, Görele Güzel Sanatlar Fakültesi Grafik Tasarımı Bölümü öğrencileri ve İstanbul Çizgi Roman okurları derneği üyelerinin değerlendirmeleriyle sınırlı olduğu unutulmamalıdır. Daha kapsamlı bir anket çalışması düzenlendiğinde verilerin değişebileceği bu araştırma sonuçları doğrultusunda öngörülebilir. Fakat Ankete katılan yaş oranlarına bakıldığında genç nesil (15-20, 20-35yaş aralığı), popüler kadın ve erkek çizgi roman karakterlerini bilmekte, orta nesil ise (40-50, 50-60), çizgi roman tarihine dayalı bilgileri ne yönelik Tina, Tommiks gibi kadın ve erkek karakterleri de bildikleri ortaya çıkmıştır. Sonuç olarak bu anket çalışmasında kadın karakterlerin nesneleştirildiği ve cinsiyet temsili açısından kadınları yansıtmadığı ortaya çıkan bulgular arasındadır. Aynı zamanda ankete göre; çoğu katılımcının çizgi romanlarda erkek karakterlerin de nesneleştirmesini doğru bulmadığı sonucuna ulaşılmıştır.

\section{SONUÇ (CONCLUSION)}

Son yıllarda kadın hareketlerinde yaşanan gelişmelerle birlikte birçok sektörde olduğu gibi çizgi roman alanında da kadın bedeninin temsili üzerine akademik anlamda çeşitli araştırmalar yapılmaktadır. Bu araştırmalar, kadın bedeninin çizgi roman alanındaki temsillerini incelemek ve anlamak için yeni yollar bulmaya dayalıdır. Nitekim sosyolojik bir araştırmayı da gerektiren bu çalışma kültürel yapının içinde gelişen toplumsal cinsiyet kavramının altında yatan sebeplerin incelenerek bu durumun değiştirilebileceğini göstermektedir. John Stuart Mill'de; "Toplumdaki yerleşmiş görüşün değiştirilebilmesinin çok zor bir sorun olduğunu belirtmiştir" [17].

Nesneleştirme hakkındaki bilimsel tartışmalarla birlikte pornografi, çıplak kadın bedenleri, kadın cinselliğinin temsilleri konusunun derinlemesine araştırılması açısından önemlidir. Çizgi romandaki bu nesneleştirilen grafik kadınlar, erkek bakışının izleğinde seyredilerek üretimi sağlandıkça sektör açısından pek bir gelişme kaydedilemeyecektir. Bu grafik kadınları okuyanların, kadın da olabileceği düşünülürse kadın temsilinin daha doğru yaratımı sağlanabilir. Kültürel bağlamda ise toplumda yaşayan bireylere yönelik cinsiyet temsillerine karşı bir bilincin eğitsel olarak geliştirilmesi gerekmektedir. Ayrıca nesneleştirmenin sadece kadın karakterlere yönelik yapılmadığı çoğu zaman erkek karakterlerin de bu duruma maruz kaldığı dikkate alınmalıdır.

Çizgi roman tarihine bakıldığında ister Türkiye'de olsun ister Dünya'da kadın karakterlerin cinsiyet temsilinin doğru yansıtılması yerine bir satış politikası olarak görülmesi, kadınları çizgi roman okumaktan alıkoymuş ya da uzaklaştırmıştır. Çünkü sektöre sunulan 
çizgi romanlar ya da dergiler, pornografik ögelerin yanı sıra toplumun yapısı gereği 'genç kızlara yönelik', 'hanım hanımcık' tabirlerinin hakim olduğu ürünlerin de ortaya koyulmasıyla kadın okuru bir başka nesneleştirme biçemine kavuşturmuştur. Kadınlar, çizgi romanda bu sefer erkek bakışı yerine toplumun isteğine göre ya da topluma uygun olarak şekillendirilmişlerdir. Ya da geçmişte çizgi romanlarda kadın karakterlerin erkek karakterlerden daha küçük ya da daha güçlü çizildiği de unutulmamalıdır. Ayrıca kadın çizerler, geçmişte çizgi romanda ismini yazmak yerine lakap dahi kullanmışlardır. Bu bağlamda çizgi roman alanında kadın cinsiyet temsilinin doğru yansıtılabilmesi açısından daha çok kadın çizer ve senariste ihtiyaç vardır. Sektörde kadınların alan hakimiyeti arttıkça, kadın söylemi ve dili daha iyi gelişecektir. Belki de yapılması gereken kadın bedeni ve temsilinin görsel bir imge olarak sunulmasından çok kadın hikayelerinin en doğru biçimde anlatılmasıdır. Örneğin; Son yıllarda Türkiye'de sadece kadın çizerlerden oluşan ve kadın hikayelerini mizahi bir yolla anlatan "Bayan Yanı" adlı bir dergi bulunmaktadır. Bu dergide bazı kadın karakterler özellikle nesneleştirilmekte ve kadın bedeni toplumsal cinsiyet yaklaşımlarını yıkmak için sıradanlaştırılmaktadır. Dolayısıyla bu noktada tümevarım yöntemini kullanmak doğru bir yaklaşım olacaktır. Bu yönteme göre; "Çizgi romanlarda bazı kadın karakterler nesneleştirilmektedir. Çizgi romanlarda bazı erkek karakterler de nesneleştirilmektedir. Öyleyse çizgi romanlarda nesneleştirme olgusuna çoğu zaman rastlanmaktadır" ifadesine ulaşılmaktadır. Ayrıca anket sonuçlarından elde edilen bulgulara göre katılımcılar, günümüz çizgi romanlarında toplumsal cinsiyet yaklaşımıyla karşılaştıklarını o94 oranında evet ile, kadın karakterlerin cinsiyet temsili olarak kadın katılımcıları temsil etmediğini 58 oranında evet ile kadın karakterleri nesneleştirilmiş biçimde okumayı sevmediklerini \%97.3 oranında evet ile, çizgi romanlarda pornografi ile karşılaştıklarını o88 oranında evet ile kabul etmişlerdir. Öte yandan katılımcıların bu cevapları verirken daha çok popüler karakterler olan Cat Woman, Wonder Woman, Batman, Süperman gibi isimler üzerinden yorumladığı görülmüştür. Fakat çoğu anket katılımcısının erkek karakterlere yapılan nesneleştirme unsurlarını da doğru bulmadığı ortaya çıkan bulgular arasındadır.

Sonuç olarak çizgi roman disiplini, eğer var olmaya devam etmek ve okur sayısını artırmak istiyorsa kadının cinsiyet temsili açısından benzer karakterler yaratmaktan vazgeçerek belli kalıpların dışına çıkmalıdır. Fakat erkek gözü ile yaratılan ve nesneleştirelen aynı karakterlerin yaratımları sürerse, okuyucuya bağlı iletişim sorunları ortaya çıkacaktır. Tüm bunların yanı sıra nesneleştirmenin sadece kadın karakterlere özgü bir durum olmadığı erkek karakterlerin de bu duruma mazur bırakıldıkları unutulmamalıdır.

\section{NOT (NOTICE)}

Bu çalışma "Kültürel Anlatılarda Amazon Kadını: Hareketli Bir Çizgi Roman Uygulaması" başlıklı sanatta yeterlik tezinden türetilmiştir.

\section{TEŞEKKÜR (ACKNOWLEDGMENT)}

Katkılarından dolayı danışmanım Sayın Prof. N. Şule Atılgan'a teşekkür ederim.

ÇIKAR ÇATIŞMASI (CONFLICT OF INTEREST)

Yazar çıkar çatışması bildirmemiştir. 
$\mathrm{Bu}$ çalışma Hacettepe Üniversitesi Bilimsel Araştırma Koordinasyon Birimi tarafından desteklenmiştir. Proje Kimliği: 9109.

\section{ETIK STANDARTLAR BEYANI (DECLARATION OF ETHICAL STANDARDS)}

Bu makalenin yazarı, bu çalışmada kullanılan materyal ve yöntemlerin etik kurul izni ve/veya yasal-özel izin gerektirmediğini beyan eder.

\section{KAYNAKLAR (REFERENCES)}

[1] Alpar, A., (2018). Oysa çizgi romanı sadece hetoreksüel erkekler okumuyor. Lacivert Öykü ve Şiir Dergisi, 80:75-82.

[2] Antmen, A., (2018). Sanat cinsiyet sanat tarihi ve feminist eleştiri (Çev. E. Soğancılar ve A. Antmen). İstanbul: İletişim Yayınları.

[3] Baker, U., (2015). Sanat ve arzu (Ed. T. Açık). İstanbul: İletişim Yayınları.

[4] Bartsky, S., (1990). Femininity and domination: studies in the phenomenology of oppression. New York/London: Routledge.

[5] Bilgin, R., (2016). Geleneksel ve modern toplumda kadın bedeni ve cinselliği. Frrat Üniversitesi Sosyal Bilimler Dergisi, $26(1): 219-243)$.

[6] Bross, W., (1976). Porky ve pentunia pig (çizgi roman). Erişim Adresi: https://www.kisa.link/Omem.

[7] Butler, J., (2018). Cinsiyet belası feminizm ve kimliğin altüst edilmesi (Çev. B. Ertür). İstanbul: Metis Yayıncılık.

[8] Cameron, D. ve Winter, C., (1942). Liberte belle (çizgi roman). Erişim Adresi: https://servimg.com/view/18913714/1258\#.

[9] Cantek, L., (2016). Çizgili hayat kılavuzu (Ed. L. Cantek).



[10] Chute, H.L., (2010). Graphic women: life narrative and contemporary comics. New York: Columbia Up.

[11] Derdiyok, R., (2019). Çizgi romanlarda kadın karakterlerin nesneleştirilmesi üzerine karşılaştırılmalı bir inceleme ve bir çizgi roman uygulaması (Yayımlanmış yüksek lisans tezi). Ankara: Hacettepe Üniversitesi Güzel Sanatlar Enstitüsü.

[12] Ellsworth, W., (1951). Batman \#65 July (çizgi roman). Erişim Adresi: https://m6p2s5gziax8.tumblr.com/post/ 137852230785 /catwoman-covers- from-the-golden-age-these-are-all.

[13] Eisner, W., (2000). Comics \& sequantial art: principles and practices form the legendary cartoonist. Florida: Poorhouse Press.

[14] Features, K., (1966). Temel Reis ve Safinaz (çizgi roman). Erişim Adresi: https://www.pinterest.com.au/pin/ $735494182886272283 /$.

[15] Features, K., (1978). Minnie Mouse ve Mickey Mouse, (çizgi roman). Erişim Adresi:https://www.kisa.link/Omet.

[16] Fish, A.H., (1920). Awful Week-ends, (çizgi roman). Erişim Adresi: https://wWw.kisa.link/Omex.

[17] Geçit, B., (2013). John Stuart Mill'de kadının toplumsal konumu. Beytulhikme An International Journal of Philosophy, 3(2):105127.

[18] Gibson, M., (2017). Comics and gender (Ed. F. Bramlett ve R. Cook). New York and Oxon: Taylor \& Frances Group.

[19] Gloeckner, P., (2002). The diary of teenage girl (çizgi roman). Erişim Adresi: https://www.kisa.link/Omey.

[20] Güngör, A., (2018). Elinin hamuruyla çizgi romana karışanlar. Profesör, 1:6. 
[21] Hatfield, C., (2005). Alternative comics: an emerging literature. Jackson: UP Mississippi.

[22] Klein, S., (1991). Breaking the mold with humor: images of women in the visual media. Marily Zurmuehlen Working Papers in Art Education, 10:29-37. DOI: 10.17077/2326-7070.1205.

[23] Kuzucular, Ş., (2016). Groteks Nedir. Erişim adresi:https://www.kisa.link/OmeA.

[24] Lavin, M.R., (1998). Women in comic books. Serials review, $24(2): 93-100$.

[25] Madrid, M., (2009). The supergirls: fashion, feminism, fantasy, and the history of comic book heroines. Ashland: Exterminating Angel.

[26] McCloud, S., (2000). Reinventing comics the evolution of an art form. NewYork: HarperCollins Publishing.

[27] Miralles, A., (2016). Djinn Volume 5 (çizgi roman). Erişim Adresi: https://www.kisa.link/OmeD.

[28] Rick, B. ve Parobeck, M., (1994). Batman Adventures Vol 1 \#23 (çizgi roman). Erişim Adresi: https://www.kisa.link/OmeG.

[29] Robbins, T., (2002). Gender differences in comics. Image \& Narrative Online Magazine, Issue: 4.

[30] Robbins, T., (2005). Comic book examining pop culture (Ed. D.M. Haugen). USA: Thomson Gale.

[31] Simone, G., (1994). Women in refrigators syndrome (çizgi roman). Green Lanterne \#54. Erişim adresi: https://www.kisa.link/OmeH.

[32] Stuller, J.K., (2012). Critical approaches to comics theories and methods (Ed. M.J. Smith, ve R. Duncan). New York and London: Routledge.

[33] Şeker, B., (2013). Başkaldıran bedenler türkiye'de transgender, aktivizm ve altkültürel pratikler. İstanbul: Metis Yayınları.

[34] Türk, B.H., (2013). Hayali kahramanlar hakiki erkekeler çizgi roman ve fotoromanda erkeklik temsilleri üzerine denemeler. İstanbul: İletişim Yayınları.

[35] Versaci, R., (2007). This book contains graphic language: comics as literature. New York and London: Continuum International Publishing.

[36] Wolk, D., (2007). Reading comics: how graphic novels work and what they mean. Cambridge: Da Capo Press. 